\title{
Design of Online Healthcare Systems
}

\author{
A.Suresh Kumar, S.Fabiyola Kavitha
}

\begin{abstract}
Medical Representatives play a major role in pharmaceutical industries in terms of promoting pharmaceutical products to the physicians. The role of physicians in deciding the therapy is still dominant, but in some areas like OTC brands, patients have more and more power to choose between the products. Other important target customers are the pharmacists, hospitals, wholesalers, governmental forces and so on.
\end{abstract}

Pharmaceutical companies direct their medical representatives' efforts towards physicians. The medical representatives efforts directed at physicians comprise personal selling through representatives' detailing; sampling (provision of drugs at free of cost); physician meetings and events; advertisements in medical journals; conducting CME/RTM also.

The new trends of pharmaceutical marketing are affected by the trends of the pharmaceutical industry itself. The number of new innovative drugs is less and less in connection with the increasing $R \& D$ (Research \& Development) costs. The development cost of a new drug (including the research cost of the unsuccessful substances) is around 800 million USD. According to industry experts, $R \& D$ is no longer the industry's driving force for growth. Even if the new drug is more effective and has less side effect (this is the pivotal elemental of the drug's quality) than the other ones available in the market that is not drug producer, developing its marketing activity of medical representatives may be the key of success..

Keywords: Medical Representatives, Pharmaceutical Companies, marketing efforts \& Physicians.

\section{INTRODUCTION}

To describe the role of the different marketing professionals like medical representatives and physicians, both during the prescription processes well as after. To analyze the physicians' prescription process inside the firm followed by the factors that influence by medical representatives

- To examine the roles and effectiveness of medical representatives in the pharmaceuticals industry.

- To evaluate the competitive strategies followed by different companies and their representatives.

\section{RESEARCH DESIGN}

The total sample respondents of 60 at various levels of physicians are selected by adopting proportionate random sampling technique and the data and information are

Revised Manuscript Received on September 22, 2019.

A.Suresh Kumar, Research Scholar, Bharath Institue Of Higher Eduction And Research, Chennai, emalsuresh@rediffmail.com

Dr.S.Fabiyolakavitha, Mba. ,M.Phil. ,Pgdhrm., Net. ,Ph.D., Associate Professor, Bharath Institute Of Higher Education And Research,Chennai the only factor which its success. To remain profitable, for a

collected through pre-tested interview schedule. In the final stage, this study combined the expert group's opinions, and interviewed each expert again to gather individual results for the carrying out the research.

\section{STATISTICAL TECHNIQUE}

The data and information collected would be analyzed by using different marketing research techniques like, Descriptive Statistics, Multiple-Regression Analysis, Cluster Analysis, Chi-Square Test and Constrains Analysis based on the nature and availability of data and information.

Results and Discussions

\section{Factor Influencing the Prescription}

The distribution of factors influencing the prescription decisions of pharmaceutical products was analyzed and the results are presented in Table 1.

Table-1. Distribution of Factors Influencing the Prescription

Decision of Pharmaceutical Products by the Physicians

\begin{tabular}{|c|c|c|c|}
\hline Influencer & Frequency & Per Cent & $\begin{array}{c}\text { Chi } \\
\text { Square } \\
\text { Value } \\
\end{array}$ \\
\hline $\begin{array}{l}\text { Medical } \\
\text { Representatives }\end{array}$ & 45 & 75 & \multirow{6}{*}{0.07} \\
\hline $\begin{array}{l}\text { Internet/Magazine } \\
\mathrm{s}\end{array}$ & 4 & 6.67 & \\
\hline $\begin{array}{l}\text { Advertisement in } \\
\text { medical journals }\end{array}$ & 3 & 5 & \\
\hline Product Trail & 3 & 5 & \\
\hline Self & 2 & 3.33 & \\
\hline Other & 3 & 5 & \\
\hline Total & 60 & 100 & \\
\hline
\end{tabular}

From the table, it is clear that about 75.00 per cent consumers' prescription decision of the pharmaceutical products is influenced by medical representatives' information from a doctor followed by internet /magazine (6.67 per cent), advertisements in medical journals, product trail and other reasons (5.00 percent) and self (3.33 per cent). The Chi-square value of 0.07 is significant at five per cent 


\section{Design of Online Healthcare Systems}

level indicating that there is a significant difference in factors influencing consumers' purchase decision of the pharmaceutical products.

\section{Brand Features of Pharmaceutical Products}

The brand features of Pharmaceutical products prescribed by the physicians were analyzed and the results are presented in Table 2.

Table-2. Distribution of Brand Features of Pharmaceuticals Products Prescribed by the Physicians

\begin{tabular}{|c|c|c|c|c|}
\hline $\begin{array}{l}\text { Brand } \\
\text { Features }\end{array}$ & Frequency & $\begin{array}{l}\text { Per } \\
\text { Cent }\end{array}$ & $\begin{array}{l}\text { Chi } \\
\text { Square } \\
\text { Value }\end{array}$ & Sig \\
\hline $\begin{array}{l}\text { Scientifical } \\
\text { information } \\
\text { from the } \\
\text { Medical } \\
\text { Representatives }\end{array}$ & 52 & 86.7 & \multirow{5}{*}{0.05} & \multirow{5}{*}{0.04} \\
\hline Brand Name & 2 & 3.3 & & \\
\hline Pricing & 3 & 5 & & \\
\hline Other reason & 3 & 5 & & \\
\hline Total & 60 & $0^{10}$ & & \\
\hline
\end{tabular}

From the results, it is observed that about 86.70 per cent of the physicians select the pharmaceutical products based on scientifical information given by the medical representatives followed by pricing and other reasons (5.00 per cent) and brand name (3.30 per cent). The Chi-square of 0.05 is significant at five per cent level indicating that there is a significant difference in brand features of pharmaceutical products prescribed by the physicians.

\section{Primary Intention to meet Physicians by Medical Representatives}

The primary intention to meet physicians to promote either branded or generic pharmaceutical products was analyzed and the results are presented in Table 3.

Table-3. Primary Intention to meet Physicians for Promote their Branded (or) Generic Pharmaceutical Products by Medical Representatives

\begin{tabular}{|l|c|c|c|c|}
\hline $\begin{array}{c}\text { Primary } \\
\text { Intention to } \\
\text { Promote } \\
\text { Branded or } \\
\text { Generic } \\
\text { Pharmaceutical } \\
\text { Products }\end{array}$ & Frequency & Per Cent & $\begin{array}{c}\text { Chi } \\
\text { Square } \\
\text { Value }\end{array}$ & Sig \\
\cline { 1 - 3 } $\begin{array}{l}\text { Branded } \\
\text { Products }\end{array}$ & 46 & 76.7 & \multirow{2}{*}{0.02} & \multirow{2}{*}{0.03} \\
\cline { 1 - 3 } $\begin{array}{l}\text { Generic } \\
\text { Products }\end{array}$ & 14 & 23.3 & 100 & \\
\hline Total & 60 & \multicolumn{2}{|c|}{} & \\
\hline
\end{tabular}

\section{RESULT AND CONCLUSION}

The results show that about 76.60 per cent of medical representatives' primary intention to meet physicians for promote their branded pharmaceutical products, while the rest of 23.30 per cent representatives' primary intention to visit drug store to promote generic pharmaceutical products. The Chi-square value of 0.02 is significant at five per cent level indicating that there is a significant difference in medical representatives' primary intension to visit drug store to promote their branded pharmaceutical products and remaining 23.30 per cent representatives' primary intention to meet physicians and pharmacy also to promote generic pharmaceutical products.

\section{REFERENCES}

1) Chen, Hsiu-Shu (2000), "A study of competitive strategies of brand name athletic footwear in Taiwan”, Unpublished Dissertation, National Univ. of Taiwan, Taipei.

2) Day, G. S., and R. Wensley (1998), " Assessing Advantage: A Framework for Diagnosing Competitive Superiority," Journal of Marketing, 52(Apr), 1-19.

3) Fang, Chih-Hui (1996), “A Study on Prescriptions Released from NHI Contract Hospitals and Clinics", Unpublished Dissertation, National Univ. of Chen-Gong, Taiwan.

4) Ghemawat, Pankaj, Collis David J., Pisano Gary P. and Rivkin Jan W (1999), Strategy and The Business Landscape, Addison, Wesley, Longman Inc.

5) Grant, Robert M. (2001), Contemporary Strategy Analysis: Concepts, Techniques, Application, Malden, MA: Blackwell Publishers.

6) Hofer, C. W. and Schendel D. (1985), "Strategy Formulation: Analytica Concept", Weat Publishing, New York.

7) Huang, Chung-Ming (1996), “A Preliminary Study on the New Drug Launch Process of International research-based Pharma- ceuticals and the Protection of Intellectual Property Rights", Unpublished Dissertation, National Univ. of Chen-Gong, Taiwan. 